\section{Paroxysmale nächtliche Dystonie}

Helga Peter

Marburg, Deutschland

\section{Englischer Begriff}

paroxysmal nocturnal dystonia

\section{Definition}

In Unkenntnis ihrer epileptischen Genese wurde der Begriff für die Symptomatik der Autosomal dominanten nächtlichen Frontallappenepilepsie (ADNFLE) verwendet.

Siehe auch $\triangleright$,Epilepsie“. 